\title{
Anxiety, stress and depression in family members of patients with heart failure*
}

\author{
Ansiedade, estresse e depressão de familiares de pacientes com insuficiência cardíaca \\ Ansiedad, estrés y depresión de familiares de pacientes con insuficiencia cardiaca
}

\section{Marianna Sobral Lacerda ${ }^{1}$, Melissa Alves Cirelli ${ }^{1}$, Alba Lúcia Bottura Leite de Barros ${ }^{1}$, Juliana de Lima Lopes ${ }^{1}$}

How to cite this article:

Lacerda MS, Cirelli MA, Barros ALBL, Lopes JL. Anxiety, stress and depression in family members of patients with heart failure. Rev Esc Enferm USP. 2017;51:e03211. DOI: http://dx.doi.org/10.1590/S1980-220X2016018903211

\begin{abstract}
* Extracted from the dissertation "Ansiedade, estresse e depressão de familiares de pacientes com insuficiência cardíaca”, Escola Paulista de Enfermagem, Universidade Federal de São Paulo, 2015.

${ }^{1}$ Universidade Federal de São Paulo, Escola Paulista de Enfermagem, São Paulo, SP, Brazil
\end{abstract}

\section{ABSTRACT}

Objective: Identifying the level of anxiety, stress and depression symptoms in family members of patients with heart failure; identifying the relationship between these feelings with sociodemographic and clinical variables. Method: A cross-sectional study carried out with 100 family members. Depression, anxiety, and stress were evaluated by the Beck Depression and Anxiety Inventories and the Perceived Stress Scale - 10. The relationship between feelings and variables was performed through the t-test, Mann-Whitney or Kruskal-Wallis. Results: Mean depression was 8.24, anxiety was 77.95, and stress was 17.43. The correlation coefficient between depression and anxiety and depression and stress was 0.53 , and it was 0.66 between anxiety and stress. Females $(p=0.002, p=0.031)$, smoking $(\mathrm{p}=0.05, \mathrm{p}=0.011)$ and sedentary lifestyle $(\mathrm{p}=0.023, \mathrm{p}=0.001)$ were related to anxiety and stress, respectively. Family income lower than five minimum wages $(p=0.012)$ was related to depression, and regular/poor self-perceived health status related to the three feelings. Conclusion: Family members did not present high levels of these feelings. The scales were directly correlated with each one another and some variables were related to stress, anxiety and depression.

\section{DESCRIPTORS}

Heart Failure; Family; Anxiety; Stress, Phychological; Depression; Cardiovascular Nursing. 


\section{INTRODUCTION}

Heart failure (HF) is the final pathway for various heart diseases representing a major public health problem. According to data from DataSUS, circulatory system diseases were the third leading cause of hospital admission in $2015^{(1)}$.

$\mathrm{HF}$ is a chronic disease responsible for the greatest number of hospitalizations within the group of circulatory system diseases ${ }^{(1)}$. An individual affected by a chronic disease such as HF experiences changes in their daily life which are caused by the disease itself ${ }^{(2)}$, such as changes related to the use of medicines (start taking, changing or increasing number of medications), frequent consultations and recurrent hospitalizations.

Such changes to a patient's lifestyle directly influence their family members' living habits, who represent necessary support to the patient for better coping with the disease. It is known that caregivers directly and indirectly contribute to monitoring, maintenance and management of patient self-care ${ }^{(3)}$. Therefore, understanding psychosocial factors (depression, anxiety and stress) that may be present in family members and understanding the context in which the patient and family are inserted becomes important.

It is known that family members may experience negative experiences/situations arising from care which encompass physical and psychological aspects. A study showed that family member caregivers present musculoskeletal and sleep disorders, fatigue, increased levels of stress, anxiety and social isolation due to the care (provided) (2). Worse quality of life $^{(4)}$, depression ${ }^{(5)}$ and increased burden ${ }^{(6)}$ are other negative aspects found in family members.

Negative experiences associated with time spent providing care may lead the caregiver to neglect their own health. A meta-analysis of 168 studies found that different impacts are experienced by spouses, children and stepchildren caregivers. Spouses report greater financial and physical burden, more symptoms of depression and lower psychological well-being compared to children and stepchildren ${ }^{(7)}$. A review of the literature concluded that among the main factors generating burden in family member caregivers of adults and older adults were physical and psychological exhaustion, lack of support from other family members, patient's degree of dependency, and the role of caregiver ${ }^{(8)}$.

The interest in focusing studies on families has been increasing, especially at an international level. In Brazil, this interest mainly involves family members of patients with mental disorders. To the best of our knowledge, there are no national Brazilian studies specifically evaluating depression, anxiety or stress in family members of patients with heart failure receiving outpatient care, who in their majority are in functional classification (FC) I and II, differing from those hospitalized who are FC III and IV. We emphasize that in order to carry out an intervention in any given population, it is necessary to understand it first, since the aspects involved in the act of caring vary according to the social and cultural context of these individuals.

Thus, the present study aimed at analyzing the anxiety, stress and depression symptom levels in accompanying family members of outpatients with HF; with specific objectives aimed at identifying the relationship between these feelings and each other, and the relationship of sociodemographic and clinical variables with the level of such feelings.

\section{METHOD}

This is a descriptive, cross-sectional and correlational study carried out at the Cardiomyopathy Outpatient Clinic of the Hospital São Paulo (HSP).

The sample consisted of family members of HF patients attended at the Cardiomyopathy Outpatient Clinic. Sample calculation was based on the standard deviation of anxiety, depression and stress of a pilot sample of five patients from this same outpatient clinic, using Wilcoxon's rank-sum test. A 5\% level of significance, power of $95 \%$ and standard deviation of 4.73 (standard deviation of depression, considering that this was the highest standard deviation found in comparison to stress and anxiety) were adopted, and the sample to collect from was at least 87 family members. Considering the possibility of losses, the sample size was increased by $10 \%$, equaling a minimum of 96 subjects.

The following inclusion criteria were considered: accompanying family members of $\mathrm{HF}$ patients of functional class I and II, older than 18 years, and being literate and with at least four years of education. Criteria for exclusion were: family members with chronic diseases such as HF, chronic obstructive pulmonary disease or terminal stage diseases, family members with prior medical diagnosis of psychic diseases and making use of anxiolytics and/or benzodiazepines.

Data collection covered the period from April 2014 to February 2015. During this period, all family members accompanying patients who suffered HF and who were present on the day of the medical appointment at the outpatient clinic that met the inclusion criteria were evaluated. Data collection was performed in the waiting room of the outpatient clinic on the day of the medical follow-up and prior to the consultation so as not to influence the anxiety, stress and depression assessment. A validated instrument for patients with Coronary Insufficiency and modified by the researchers of this study was used for collecting demographic and general clinical data ${ }^{(9)}$. The instruments for evaluating depression, anxiety and stress were the Beck Depression Inventory (BDI), the Beck Anxiety Inventory (BAI) and the Perceived Stress Scale (PSS-10), respectively. All instruments were self-administered, except for the sociodemographic information instrument which was conducted through an interview. After application, the questionnaires were checked to ensure all questions of the instruments had been filled in, and in the absence of any response the family member was asked to answer the question.

Variables included in the sociodemographic and clinical data instrument were gender, age, degree of relation with the patient, race, education level, marital status, family income, professional occupation, smoking habits, alcoholism, physical activity, leisure activity, body mass index (BMI), personal history (comorbidities) and self-perceived health status. The choice for these variables was determined by their association with stress, anxiety and/or depression in previous studies ${ }^{(6,10-15)}$. 
Self-perceived health status was determined by the question: How is your overall health? The World Health Organization uses the following categories: 1: very good; 2: good; 3: regular; 4: poor 5: very poor ${ }^{(16)}$.

Beck Depression Inventory (BDI) is a self-administered instrument composed of 21 items, each containing four alternatives that express levels of severity of depression symptoms, ranging from 0 to 63 . The score for each category ranges from zero to three, with zero representing the absence of depression symptoms and three the presence of intense symptoms, and the individuals choose only one of the alternatives. The symptoms are evaluated in relation to their last week. The Portuguese scale presents internal consistency of 0.81 among the sample of students, and 0.88 among the sample of depressed patients ${ }^{(17)}$. The following categorization was used to assess the symptoms of depression: scores ranging from 0 to $14-$ no symptoms of depression; scores ranging from 15 to 19 - symptoms of dysphoria; scores of 20 or more - symptoms of depression ${ }^{(18)}$.

Beck Anxiety Inventory (BAI) is an assessment tool for characterizing symptoms of anxiety. It was developed to meet the needs of an instrument which can reliably discriminate anxiety from depression ${ }^{(19)}$. The scale consists of 21 items that reflect somatic, cognitive and affective manifestations characteristic of anxiety, and refers to the symptoms that affected the individual in the last week, ranging from 0 to 63. For each question, the individual should choose one of four anxiety levels on a Likert scale ranging from 0 to 3 . The level of anxiety is classified into normal anxiety when the total score varies between 0 and 9 points, as mild to moderate anxiety when the total score obtained is between 10 and 18 points, as moderate to severe anxiety when it ranges from 19 to 29 points, and as severe anxiety from 30 to 63 points ${ }^{(20)}$. Evaluation of psychometric properties was carried out on samples of psychiatric, medical-clinical and non-clinical patients. Cronbach's alpha ranged from 0.71 to 0.92 in the non-clinical sample and from 0.75 to 0.92 in the medical-clinical sample ${ }^{(21)}$.

Stress levels were assessed using the Perceived Stress Scale -10 (PSS-10). The Perceived Stress Scale is composed of 10 questions and was validated in Brazil in $2010^{(22)}$. PSS10 is composed of 10 questions which correlate events and situations that occurred in the last 30 days with a score of 0 (never) to 4 (very frequent), where the individual only chooses one of the alternatives. The total score varies from 0 to 40 , and the higher the score, the greater the perception of stress ${ }^{(23)}$. The Portuguese version of the PSS-10 was tested in adult and older adult samples, demonstrating satisfactory reliability and validity data. The scale obtained coefficient of internal consistency of $0.86^{(22)}$ and $0.83^{(23)}$ respectively.

The present study was submitted and approved by the Research Ethics Committee of the Federal University of São Paulo, under number 521.916/2014. This project was conducted in accordance with the recommendations of Good Clinical Practices and Resolution 466 of 2012 of the National Health Council/Ministry of Health. Prior to inclusion, the subjects were duly informed about the study objectives, signed the Clear and Informed Consent Form, were guaranteed confidentiality and the possibility of withdrawal of consent at any time, if desired.
Absolute and relative frequencies were used for qualitative variables and mean, standard deviation (SD), standard error (SE), median, interquartile range (IR), maximum and minimum for quantitative variables in order to describe sample characterization. The Spearman Correlation Coefficient was used to analyze the correlation between the three scales (Depression, Stress and Anxiety). The following values of $r$ were considered to classify the strength of the correlation: 0.00-0.19 (very weak), 0.20-0.39 (weak), 0.40-0.59 (moderate), 0,60-0.79 (strong) and 0.80-1.0 (very strong) ${ }^{(24)}$.

The relationship between the scales and the qualitative variables with only two categories was tested using the twotailed t-test or the Mann-Whitney test. The relationship between the scales and the qualitative variables with three or more categories was verified by the non-parametric KruskalWallis test, and in cases where a significant relation was found, multiple comparisons of the two to two categories were performed by Tukey's non-parametric test. The relationship between the quantitative variables and the scales was tested using the Spearman Correlation Coefficient. The level of significance used was 0.05 and statistical analyses were carried out using R 3.1.2 free software.

\section{RESULTS}

The study sample consisted of 100 family members of patients with heart failure, having a mean age of $45.43 \pm 13.53$ years. Most family members were females (81\%), white (63\%) and married (61\%). Regarding their degree of relation with the patient, $40 \%$ were spouses, $36 \%$ were children and $24 \%$ were other relatives, such as siblings or daughter-inlaws/son-in-laws. They presented a mean of $9.99 \pm 3.91$ years education level, with a minimum of 4 and a maximum of 19 years, $62 \%$ were economically active at the moment of data collection and $50 \%$ survived on less than three minimum wages as family income.

Regarding the clinical data, $66 \%$ of the interviewees had no comorbidities, $88 \%$ did not smoke and $82 \%$ even refused to alcoholic beverages socially. Concerning BMI, $2 \%$ were underweight, $34 \%$ were in the normal range, $39 \%$ were overweight, and $25 \%$ were obese. Only $32 \%$ reported practicing physical activity and $47 \%$ practiced leisure activities. When asked how they would rate their overall health, $67 \%$ rated it as very good/good, and $33 \%$ as regular/poor.

Depression score presented a mean of $8.24 \pm 7.14$, with a minimum of 0 and a maximum of 32 points $(85 \%$ did not present depression symptoms, $8 \%$ had dysphoria symptoms and $7 \%$ had depression symptoms). Anxiety score presented a mean of $7.95 \pm 7.61$, with a minimum of 0 and a maximum of 36 points $(68 \%$ presented normal anxiety level, $23 \%$ mild to moderate anxiety, $8 \%$ moderate to severe anxiety and $1 \%$ severe anxiety). The Stress Scale presented a mean of $17.43 \pm 7.15$, with a minimum of 2 and a maximum of 35 points $(65 \%$ had lower levels of stress and $35 \%$ had higher levels of stress). A moderate correlation was observed between depression and anxiety, between depression and stress, and a strong correlation between anxiety and stress (Table 1). 
Table 1 - Assessment of depression, anxiety, stress and correlation between scales - São Paulo, SP, Brazil, 2014/2015.

\begin{tabular}{|c|c|c|c|c|c|c|}
\hline Scale & Scale & Mean/SD & Minimum & Maximum & Correlation & p-value \\
\hline Depression & - & $8.24 / 7.14$ & 0 & 32 & - & - \\
\hline Anxiety & - & $7.95 / 7.61$ & 0 & 36 & - & - \\
\hline Stress & - & $17.43 / 7.15$ & 2 & 35 & - & - \\
\hline Depression & Anxiety & & & & 0.53 & $<0.001$ \\
\hline Depression & Stress & & & & 0.53 & $<0.001$ \\
\hline Anxiety & Stress & & & & 0.66 & $<0.001$ \\
\hline
\end{tabular}

SD: standard deviation. Note: $(\mathrm{n}=100)$.

Depression had a significant relationship with self-perceived health and family income, while anxiety and stress had a significant relationship with gender, smoking habit, physical activity and self-perceived health (Tables 2 and 3 ).

Table 2 - Relation between depression, anxiety and stress and sociodemographic and clinical variables - São Paulo, SP, Brazil, $2014 / 2015$.

\begin{tabular}{|c|c|c|c|c|c|c|}
\hline $\begin{array}{l}\text { Sociodemographic and clinical } \\
\text { variables }\end{array}$ & $\begin{array}{l}\text { Depression } \\
\text { mean }\end{array}$ & $\begin{array}{c}\text { p-value } \\
\text { (Depression) }\end{array}$ & $\begin{array}{l}\text { Anxiety } \\
\text { mean }\end{array}$ & $\begin{array}{l}\text { p-value } \\
\text { (Anxiety) }\end{array}$ & $\begin{array}{l}\text { Stress } \\
\text { mean }\end{array}$ & $\begin{array}{l}\text { p-value } \\
\text { (Stress) }\end{array}$ \\
\hline $\begin{array}{l}\text { Gender } \\
\text { Female }(n=81) \\
\text { Male }(n=19)\end{array}$ & $\begin{array}{l}8.54 \\
6.95\end{array}$ & $0.182^{*}$ & $\begin{array}{l}8.88 \\
4.00\end{array}$ & $0.002 *$ & $\begin{array}{c}18.2 \\
14.16\end{array}$ & $0.031+$ \\
\hline $\begin{array}{l}\text { Marital status } \\
\text { Married }(n=61) \\
\text { Not married }(n=39)\end{array}$ & $\begin{array}{l}7.36 \\
9.62\end{array}$ & $0.181^{*}$ & $\begin{array}{l}7.26 \\
9.03\end{array}$ & $0.205^{*}$ & $\begin{array}{l}16.70 \\
18.56\end{array}$ & $0.212+$ \\
\hline $\begin{array}{l}\text { Professional occupation } \\
\text { Active }(n=62) \\
\text { Not active }(n=38)\end{array}$ & $\begin{array}{l}7.79 \\
8.97\end{array}$ & $0.338^{*}$ & $\begin{array}{l}6.97 \\
9.55\end{array}$ & $0.086^{*}$ & $\begin{array}{l}17.16 \\
17.87\end{array}$ & $0.624 t$ \\
\hline $\begin{array}{l}\text { Comorbidities } \\
\text { Presence }(n=34) \\
\text { Absence }(n=66)\end{array}$ & $\begin{array}{l}9.03 \\
7.83\end{array}$ & $0.664^{*}$ & $\begin{array}{l}8.24 \\
7.80\end{array}$ & $0.418^{*}$ & $\begin{array}{l}16.50 \\
17.91\end{array}$ & $0.34+$ \\
\hline $\begin{array}{l}\text { Smoking } \\
\text { Yes }(n=12) \\
\text { No }(n=88)\end{array}$ & $\begin{array}{l}8.58 \\
8.19\end{array}$ & $0.79 *$ & $\begin{array}{c}12.67 \\
7.31\end{array}$ & $0.05^{*}$ & $\begin{array}{l}20.92 \\
16.95\end{array}$ & $0.011+$ \\
\hline $\begin{array}{l}\text { Physical activity } \\
\text { Yes }(n=32) \\
\text { No }(n=68)\end{array}$ & $\begin{array}{l}6.59 \\
9.01\end{array}$ & $0.254^{*}$ & $\begin{array}{l}5.81 \\
8.96\end{array}$ & $0.023^{*}$ & $\begin{array}{l}13.91 \\
19.09\end{array}$ & $0.001+$ \\
\hline $\begin{array}{l}\text { Alcohol consumption } \\
\text { Yes }(n=18) \\
\text { No }(n=82)\end{array}$ & $\begin{array}{c}10.61 \\
7.72\end{array}$ & $0.235^{*}$ & $\begin{array}{c}10.44 \\
7.40\end{array}$ & $0.378^{*}$ & $\begin{array}{l}17.72 \\
17.37\end{array}$ & $0.853+$ \\
\hline $\begin{array}{l}\text { Leisure Activity } \\
\text { Presence }(n=47) \\
\text { Absence }(n=53)\end{array}$ & $\begin{array}{l}7.09 \\
9.26\end{array}$ & $0.422 *$ & $\begin{array}{l}7.91 \\
7.98\end{array}$ & $0.515^{*}$ & $\begin{array}{l}16.49 \\
18.26\end{array}$ & $0.222+$ \\
\hline $\begin{array}{l}\text { Degree of relation } \\
\text { Spouse }(n=40) \\
\text { Child }(n=36) \\
\text { Other }(n=24)\end{array}$ & $\begin{array}{l}8.18 \\
9.25 \\
6.83\end{array}$ & $0.795 \ddagger$ & $\begin{array}{l}7.90 \\
7.92 \\
8.08\end{array}$ & $0.875 \ddagger$ & $\begin{array}{l}16.98 \\
17.53 \\
18.04\end{array}$ & $0.953 \neq$ \\
\hline $\begin{array}{l}\text { Race } \\
\text { Asian }(n=2) \\
\text { White }(n=63) \\
\text { Black/mixed }(n=35)\end{array}$ & $\begin{array}{l}2.50 \\
7.68 \\
9.57\end{array}$ & $0.182 \neq$ & $\begin{array}{l}3.50 \\
7.75 \\
8.57\end{array}$ & $0.735 \ddagger$ & $\begin{array}{l}15.00 \\
17.38 \\
17.66\end{array}$ & $0.803 \neq$ \\
\hline $\begin{array}{l}\text { BMI } \\
\text { Underweight }(n=2) \\
\text { Normal }(n=34) \\
\text { Obese }(n=25) \\
\text { Overweight }(n=39)\end{array}$ & $\begin{array}{l}10.50 \\
7.76 \\
7.72 \\
8.87\end{array}$ & $0.635 \ddagger$ & $\begin{array}{l}4.00 \\
9.00 \\
7.04 \\
7.82\end{array}$ & $0.849 \neq$ & $\begin{array}{l}18.50 \\
18.29 \\
15.28 \\
18.00\end{array}$ & $0.275 \neq$ \\
\hline $\begin{array}{l}\text { Self-perceived health } \\
\text { Good }(n=53) \\
\text { Very good }(n=14) \\
\text { Regular }(n=31) \\
\text { Poor }(n=2)\end{array}$ & $\begin{array}{c}6.91 \\
5.21 \\
11.71 \\
11.00\end{array}$ & $0.004 \neq$ & $\begin{array}{c}7.66 \\
3.43 \\
10.61 \\
6.00\end{array}$ & $0.02 \neq$ & $\begin{array}{l}16.94 \\
13.64 \\
20.29 \\
12.50\end{array}$ & $0.008 \neq$ \\
\hline $\begin{array}{l}\text { Family income } \\
3 \text { to } 5 \mathrm{MW}(\mathrm{n}=30) \\
\text { More than } 5 \mathrm{MW}(\mathrm{n}=20) \\
\text { Less than } 3 \mathrm{MW}(\mathrm{n}=50)\end{array}$ & $\begin{array}{l}9.07 \\
4.40 \\
9.28\end{array}$ & $0.012 \ddagger$ & $\begin{array}{l}8.87 \\
5.25 \\
8.48\end{array}$ & $0.138 \neq$ & $\begin{array}{l}18.97 \\
15.10 \\
17.44\end{array}$ & $0.15 \neq$ \\
\hline
\end{tabular}




\begin{tabular}{|c|c|c|c|c|c|c|}
\hline htinuation & & & & & & \\
\hline \multirow[t]{2}{*}{$\begin{array}{c}\text { Sociodemographic and clinical } \\
\text { variables }\end{array}$} & $\begin{array}{l}\text { Depression } \\
\text { mean }\end{array}$ & $\begin{array}{c}\text { p-value } \\
\text { (Depression) }\end{array}$ & $\begin{array}{l}\text { Anxiety } \\
\text { mean }\end{array}$ & $\begin{array}{l}\text { p-value } \\
\text { (Anxiety) }\end{array}$ & $\begin{array}{l}\text { Stress } \\
\text { mean }\end{array}$ & $\begin{array}{l}\text { p-value } \\
\text { (Stress) }\end{array}$ \\
\hline & Correlation & & Correlation & & Correlation & \\
\hline Age & 0.01 & 0.933 & 0.09 & 0.355 & -0.09 & 0.352 \\
\hline Years of education & -0.09 & 0.398 & 0 & 0.992 & -0.06 & 0.526 \\
\hline
\end{tabular}

Legend: BMI - Body Mass Index; MW - Minimum wage; *Mann-Whitney two-tailed test; † two-tailed t-test; $\ddagger$ Kruskal-Wallis. Note: (n=100).

Table 3 - Multiple comparisons (non-parametric Tukey test) for variables with more than three categories that had significant relationship between the scales - São Paulo, SP, Brazil, 2014/2015.

\begin{tabular}{|c|c|c|c|}
\hline Scale & Variable & Category 1 vs Category 2 & p-value \\
\hline \multirow{3}{*}{ Depression } & \multirow{3}{*}{$\begin{array}{l}\text { Family } \\
\text { income }\end{array}$} & more than $5 \mathrm{MW}$ vs 3 to $5 \mathrm{MW}$ & 0.019 \\
\hline & & less than $3 \mathrm{MW}$ vs 3 to $5 \mathrm{MW}$ & 0.996 \\
\hline & & $\begin{array}{l}\text { less than } 3 \mathrm{MW} \text { vs } \\
\text { more than } 5 \mathrm{MW}\end{array}$ & 0.007 \\
\hline \multirow{6}{*}{ Depression } & \multirow{6}{*}{$\begin{array}{l}\text { Self-perceived } \\
\text { health }\end{array}$} & very good vs good & 0.693 \\
\hline & & regular vs good & 0.115 \\
\hline & & poor vs good & 0.067 \\
\hline & & regular vs very good & 0.095 \\
\hline & & poor vs very good & 0.019 \\
\hline & & poor vs regular & 1 \\
\hline \multirow{6}{*}{ Anxiety } & \multirow{6}{*}{$\begin{array}{l}\text { Self-perceived } \\
\text { health }\end{array}$} & very good vs good & 0.202 \\
\hline & & regular vs good & 0.235 \\
\hline & & poor vs good & 0.968 \\
\hline & & regular vs very good & 0.006 \\
\hline & & poor vs very good & 0.061 \\
\hline & & poor vs regular & 0.598 \\
\hline \multirow{6}{*}{ Stress } & \multirow{6}{*}{$\begin{array}{l}\text { Self-perceived } \\
\text { health }\end{array}$} & very good vs good & 0.382 \\
\hline & & regular vs good & 0.12 \\
\hline & & poor vs good & 0.015 \\
\hline & & regular vs very good & 0.023 \\
\hline & & poor vs very good & 0.983 \\
\hline & & poor vs regular & 0 \\
\hline
\end{tabular}

Legend: MW - Minimum wage. Note: $(\mathrm{n}=100)$.

It was observed that females, smokers and sedentary individuals had more anxiety and stress, while individuals with a family income lower than five minimum wages presented higher levels of depression. Regarding self-perceived health, those who perceived it as poor are more depressed than those who reported it as very good, and less stressed than those who perceived it as good or regular. Those who referred to health as regular are more anxious and stressed than those who reported it as very good.

\section{DISCUSSION}

Family members evaluated in the present study for the most part showed an absence of depression symptoms and normal anxiety. This same result was not found in another study in which $56.9 \%$ of family members presented depression symptoms and $46.6 \%$ presented anxiety ${ }^{(25)}$; these are high levels when compared to the current study. However, these symptoms were only evaluated in spouses considered by the patients as their main caregivers. Greater affection closeness and the over-responsibility for being primary caregivers may justify the levels of depression and anxiety. The mean stress level found in the present study was 17.43 , a result close to that found in caregivers of dependent older adults $(18.5 \pm 9.9)$ who reported a relationship between stress levels and poor or very poor self-perceived health, difficulty sleeping, and high levels of burden related to care, among others ${ }^{(26)}$.

Low depression, anxiety and stress scores found in the majority of family members evaluated in the present study can be justified by the fact that the patients were not hospitalized and because they had FC I and II HF, so they were not dependent on their family member for carrying out their (daily life) activities. A study showed that family members of HF patients with FC III/IV reported higher levels of anxiety, more time spent performing care activities, more difficulty with these activities and worse quality of life when compared to caregivers of patients who presented less symptoms of the disease $(\mathrm{FC} \mathrm{I} / \mathrm{II})^{(10)}$.

Another result found was the correlation between anxiety, stress and depression. This relationship has been studied by different areas, and can be explained by the alteration that occurs in the hypothalamic-pituitary-adrenal axis (HPA axis) due to stress, which would imply in depression ${ }^{(27)}$ and anxiety ${ }^{(28)}$ physiopathologies. In addition to the HPA axis, this relationship can also be determined by other factors such as the occurrence of stressful events in early life and by genetic factors ${ }^{(27)}$.

An association between depression and lower family income was found in the present study. Although studies evaluating this relationship in family members of $\mathrm{HF}$ patients were not found, the association of anxiety and depression symptoms with low family income was found in individuals with chronic obstructive pulmonary disease ${ }^{(11)}$. Depression was related to self-perceived health, a relationship also found with anxiety and stress. Family members who reported their health as regular or poor showed more depression symptoms and higher levels of anxiety and stress. A systematic review of 11 Brazilian articles identified a variation in the negative prevalence of self-perceived health between $12.6 \%$ and $51.9 \%$, and found that family income, difficulties or inability to perform activities of daily living, presence of depression and anxious symptoms, and others were among the dependent variables associated with negative self-perceived health ${ }^{(12)}$.

In this study, we found that women presented higher levels of anxiety and stress. The presence of stress and psychiatric disorders in women has been reported in the literature, and may be related to female hormones, their reproductive 
cycle phase $^{(29)}$ and domestic activities ${ }^{(13)}$. Another factor that should be considered in the analysis is the accumulation of tasks performed by women, which can increase stress levels.

As determined in the literature, anxiety and stress were related to the smoking. A study has shown that quitting smoking is associated with reduced depression, anxiety and stress when compared to smokers ${ }^{(14)}$. The causal relationship between anxiety, stress and smoking is still not well defined, but it is known that substances present in cigarettes such as nicotine can promote changes in the body that range from the neurotransmitter system to mitochondrial dysfunction. These changes would predispose a person to develop and/or increase anxiety ${ }^{(30)}$. Regarding physical activity, a study with European youth identified that the frequency of exercise performance is associated with levels of depression, anxiety and well-being; knowing that the higher the frequency of physical activity, the lower the depression symptoms and the anxiety levels, in addition to improving general well-being ${ }^{(15)}$.

We emphasize that the family member sample did not present high levels of stress, anxiety or depression; the relational results of the evaluated variables cannot be exacerbated to include family members with very high degrees of these feelings, which would require further studies on the subject.

Considering that family members contribute to patients' self-care ${ }^{(3)}$ and that anxiety, depression and stress of these family members influence the care of these individuals, it is suggested that nurses include an evaluation of these feelings in planning their interventions. Despite high levels of anxiety, stress and depression not having been found, we believe that this evaluation may contribute to distinguishing family members who require interventions to reduce those feelings in order to improve their quality of life, and to identify patients who need further support beyond that provided by family members.
This study presented limitations that refer to aspects of the collection environment and the research subjects. Data collection was performed in the waiting room of the outpatient clinic while the patient and their family members waited to be seen by the doctor. Using a common area for all patients may have influenced the subject's concentration, since other patients were also in the waiting room. Moreover, conducting the study in a single center may have compromised generalizing the results. With regard to the subjects, it was not well established whether they were only companions or if they were also the patients' caregiver; thus, the results may have been influenced by the fact that family members are only companions and not necessarily caregivers. Also, the cognitive status and understanding level of the family members were not evaluated, which may have influenced their filling out questionnaires.

\section{CONCLUSION}

The study concluded that the family members of patients with $\mathrm{HF}$ attended at the outpatient clinic did not present high levels of stress, anxiety or depression. The scales were directly correlated with each other and those for stress and anxiety were the most correlated. Self-perceived health, physical activity, smoking and gender were the factors that were related to stress and anxiety, and family income and health self-assessment were the factors related to depression symptoms. Although the present study makes it possible to identify the profile of family members of patients with FC I and II HF, thereby facilitating possible interventions aimed at this population, pertinent new studies are necessary in order to evaluate anxiety, stress and depression levels prospectively, and to identify if the levels of these feelings in this population change over time. Conducting new studies to evaluate these feelings in family members of heart failure patients with functional classes III and IV is also necessary.

\section{RESUMO}

Objetivo: Identificar o nível de ansiedade, estresse e sintomas de depressão de familiares de pacientes com insuficiência cardíaca; identificar a relação entre esses sentimentos com as variáveis sociodemográficas e clínicas. Método: Estudo transversal composto por 100 familiares. A depressão, a ansiedade e o estresse foram avaliados pelos Inventários de Depressão e Ansiedade de Beck e pela Escala de Estresse Percebido - 10. A relação dos sentimentos com as variáveis foi realizada pelo teste t, Mann-Whitney ou Kruskal-Wallis. Resultados: A média de depressão foi de 8,24, ansiedade, 7,95 e estresse, 17,43. O coeficiente de correlação entre depressão e ansiedade e depressão e estresse foi de 0,53 e de 0,66 entre ansiedade e estresse. Sexo feminino $(p=0,002 ; p=0,031)$, tabagismo ( $p=0,05 ; p=0,011)$ e sedentarismo $(\mathrm{p}=0,023 ; \mathrm{p}=0,001)$ se relacionaram com a ansiedade e estresse respectivamente. Renda familiar menor que cinco salários mínimos $(\mathrm{p}=0,012)$ se relacionou com a depressão, e autoavaliação de saúde regular/ruim se relacionou com os três sentimentos. Conclusão: Os familiares não apresentaram níveis elevados desses sentimentos. As escalas foram diretamente correlacionadas entre si e algumas variáveis se relacionaram com estresse, ansiedade e depressão.

\section{DESCRITORES}

Insuficiência Cardíaca; Família; Ansiedade; Estresse Psicológico; Depressão; Enfermagem Cardiovascular.

\section{RESUMEN}

Objetivo: Identificar el nivel de ansiedad, estrés y síntomas de depresión de familiares de pacientes con insuficiencia cardiaca; identificar la relación entre dichos sentimientos con las variables sociodemográficas y clínicas. Método: Estudio transversal compuesto de 100 familiares. La depresión, la ansiedad y el estrés fueron evaluados por los Inventarios de Depresión y Ansiedad de Beck y la Escala de Estrés Percibido - 10. La relación de los sentimientos con las variables fue realizada por la prueba t, Mann-Whitney o KruskalWallis. Resultados: El promedio de depresión fue de 8,24, ansiedad, 7,95 y estrés, 17,43. El coeficiente de correlación entre depresión y ansiedad y depresión y estrés fue de 0,53 y de 0,66 entre ansiedad y estrés. Sexo femenino ( $\mathrm{p}=0,002 ; \mathrm{p}=0,031)$, tabaquismo ( $\mathrm{p}=0,05$; 
$\mathrm{p}=0,011)$ y sedentarismo $(\mathrm{p}=0,023 ; \mathrm{p}=0,001)$ se relacionaron con ansiedad y estrés respectivamente. Renta familiar menor que cinco

salarios mínimos $(\mathrm{p}=0,012)$ se relacionó con depresión, y autoevaluación de salud regular/mal se relacionó con los tres sentimientos.

Conclusión: Los familiares no presentaron niveles elevados de esos sentimientos. Las escalas estuvieron directamente correlacionadas entre sí y algunas variables se relacionaron con estrés, ansiedad y depresión.

\section{DESCRIPTORES}

Insuficiencia Cardíaca; Familia; Ansiedad; Estrés Psicológico; Depresión; Enfermería Cardiovascular.

\section{REFERENCES}

1. Brasil. Ministério da Saúde. DATASUS. Morbidade hospitalar do SUS [Internet]. Brasília; 2015 [citado 2016 mar. 1]. Disponível em: http:// tabnet.datasus.gov.br/cgi/deftohtm.exe?sih/cnv/niuf.def

2. Bahrami M, Etemadifar S, Shahriari M, Farsani AK. Caregiver burden among Iranian heart failure Family caregivers: A descriptive, exploratory, qualitative study. Iran J Nurs Midwifery Res. 2014;19(1):56-63.

3. Buck HG, Harkness K, Wion R, Carroll SL, Cosman T, Kaasalainen S, et al. Caregivers' contributions to heart failure self-care: a systematic review. Eur J Cardiovasc Nurs. 2014;14(1):79-89.

4. Hu X, Hu X, Su Y, Qu M. Quality of life among primary family caregivers of patients qith heart failure in Southwest China. Rehabil Nurs. 2016 Jun 28. [Epub ahead of print]

5. Grigorovich A, Lee A, Ross H, Woodend AK, Forde S, Cameron JI. A longitudinal view of factors that influence the emotional wellbeing of family caregivers toindividuals with heart failure. Aging Ment Health. 2016 Apr 14:1-7. [Epub ahead of print]

6. Zincir SB, Sunbul M, Zincir S, Sunbul EA, Oguz M, Cengiz FF, et al. Burden and depressive symptoms associated with adult-child caregiving for individuals with heart failure. Scientific World J. 2014;2014:641817.

7. Pinquart M, Sörensen S. Spouses, adult children, and children-in-law as caregivers of older adults: a meta-analytic comparison. Psychol Aging. 2011;26(1):1-14.

8. Baptista BO, Beuter M, Girardon-Perlini NMO, Brondani CM, Budó MLD, Santos NO. A sobrecarga do familiar cuidador no âmbito domiciliar: uma revisão integrativa da literatura. Rev Gaúcha Enferm [Internet]. 2012 [citado 2016 abr. 12];33(1):147-56. Disponível em: http://www.scielo.br/pdf/rgenf/v33n1/a20v33n1.pdf

9. Brunori EHFR, Cavalcante AMRZ, Lopes CT, Lopes JL, Barros ALBL. Tabagismo, consumo de álcool e atividade física: associações na síndrome coronariana aguda. Acta Paul Enferm. 2014;27(2):165-72

10. Pressler SJ, Gradus-Pizlo I, Chubinski SD, Smith G, Wheeler S, Sloan R, et al. Family caregivers of patients with heart failure. A longitudinal study. J Cardiovasc Nurs. 2013;28(5):417-28.

11. Lou P, Zhu Y, Chen P, Zhang P, Yu J, Zhang N, et al. Prevalence and correlations with depression, anxiety, and other features in outpatients with chronic obstructive pulmonary disease in China: a cross-sectional case control study. BMC Pulm Med. 2012;12:53.

12. Pagotto V, Bachion MM, Silveira EA. Autoavaliação da saúde por idosos brasileiros: revisão sistemática da literatura. Rev Panam Salud Públ. 2013;33(4):302-10.

13. Hoshino A, Amano S, Suzuki K, Suwa M. Relationship between depression and stress factors in housework and paid work among Japanese women. Hong Kong J Occup Ther. 2016;27:35-41.

14. Taylor G, McNeil A, Girling A, Farley A, Lindson-Hawley N, Aveyard P. Change in mental health after smoking cessation: systematic review and meta-analysis. BMJ. 2014;348:g1151.

15. McMahon EM, Corcoran P, O’Regan G, Keeley H, Cannon M, Carli V, et al. Physical activity in European adolescents and associations with anxiety, depression and well-being. Eur Child Adolesc Psychiatry. 2017;26(1):111-22.

16. Bruin A, Picavest HSJ, Nossikov A, editors. Health interview surveys: toward international harmonization of methods and instruments. Geneva: WHO; 1996.

17. Gorenstein C, Andrade L. Validation of a Portuguese version of the Beck depression inventory and the state-trait anxiety inventory in Brazilian subjects. Braz J Med Biol Res. 1996;29(2):453-7.

18. Beck AT, Steer RA. Beck Depression Inventory: manual. San Antonio: Harcourt Brace; 1996.

19. Beck AT, Brown G, Epstein N, Steer RA. An inventory for measuring clinical anxiety: psychometric properties. J Consult Clin Psychol. 1988;56(6):893-7.

20. Creamer M, Foran J, Bell R. The Beck anxiety inventory in a non-clinical sample. Behav Res Ther.1995;33(4):477-85.

21. Cunha JA. Manual da versão em português das Escalas Beck. São Paulo: Casa do Psicólogo; 2001.

22. Reis RS, Hino AAF, Añez CRR. Perceived Stress Scale: reliability and validity study in Brazil. J Health Psychol. 2010;15(1):107-14.

23. Luft CDB, Sanches SO, Mazo GZ, Andrade A. Versão brasileira da Escala de Estresse Percebido: tradução e validação para idosos. Rev Saude Publica. 2007;41(4):606-15.

24. Evans JD. Straight forward statistics for the behavioral sciences. Pacific Grove, CA: Brooks/Cole; 1996.

25. Chung ML, Moser DK, Lennie TA, Rayens MK. The effects of depressive symptoms and anxiety on quality of life in patients with heart failure and their spouses: Testing dyadic dynamics using Actor-Partner Interdependence Model. J Psychosom Res. 2009;67(1):29-35.

26. Luchesi BM, Souza EN, Gratão AC, Gomes GA, Inouye K, Alexandre TS, et al. The evaluation of perceived stress and associated factors in elderly caregivers. Arch Gerontol Geriatr. 2016;67:7-13.

27. Mello AF, Juruena MF, Pariante CM, Tyrka AR, Price LH, Carpenter LL, et al. Depressão e estresse: existe um endofenótipo? Rev Bras Psiquiatr. 2007;29(1):S13-8. 
28. Graeff FG. Ansiedade, pânico e o eixo hipotálamo-pituitária-adrenal. Rev Bras Psiquiatr. 2007;29(1):S3-6.

29. Ter Horst JP, de Kloet ER, Schachinger H, Oitzl MS. Relevance of stress and female sex hormones for emotion and cognition. Cell Mol Neurobiol. 2012;32(5):725-35.

30. Moylan S, Jacka FN, Pasco JA, Berk M. How cigarette smoking may increase the risk of anxiety symptoms and anxiety disorders: a critical review of biological pathways. Brain Behav. 2013;3(3):302-26. 